\title{
Impact of UCP2 -866G/A Variant on Smoking Risk
}

\section{UCP2 -866G/A Varyantının Sigara İçme Durumuna Etkisi}

(iD Ayșe Feyda NURSAL ${ }^{1}$, iD Mehmet Atilla UYSAL², id Mustafa PEHLIVAN³, id Ülgen SEVER 4 , id Sacide PEHLIVAN4

'Hitit University Faculty of Medicine, Department of Medical Genetics, Çorum, Turkey

2University of Health Sciences Turkey,Yedikule Hospital For Chest Diseases and Thoracic Surgery Training and Research Hospital, Clinic of

of Chest Diseases, İstanbul, Turkey

${ }^{3}$ Gaziantep Univesity Faculty of Medicine, Department of Hematology, Gaziantep, Turkey

${ }^{4}$ İstanbul University İstanbul Faculty of Medicine, Department of Medical Biology, İstanbul, Turkey

\section{ABSTRACT}

Objective: Mitochondria are multifunctional and dynamic organelles found in cells. Nicotine is a natural alkaloid found in the tobacco plant and has been well studied as a component of cigarette smoke. It has also been reported to affect mitochondrial function both in vitro and in vivo. Uncoupling protein 2 (UCP2) reduces generation of ROS by mitochondria. Our purpose in this study was to investigate whether the $-866 \mathrm{G} / \mathrm{A}$ variant of the UCP2 gene is associated with smoking status.

Methods: A total of 238 individuals consisting of 138 smokers and 100 healthy controls were examined. The UCP2-866G/A variant was genotyped by polymerase chain reaction-restriction fragment length polymorphism method.

Results: The proportion of individuals carrying the three possible genotype was significantly different between the smoker and healthy control groups. The UCP2-866G/A variant GG genotype was associated significantly with an increased risk of smoking ( $\mathrm{p}=0.001)$ while AA genotype was associated significantly with a decreased risk of smoking ( $\mathrm{p}=0.001)$. The UCP2-866G/A variant $\mathrm{G}$ allele was found to be increased in the smoker group compared to the healthy controls ( $\mathrm{p}=0.001)$.

Conclusion: Our data suggest that the UCP2-866 G/A variant GG genotype and $\mathrm{G}$ allele might reflect the risk of smoking status in a Turkish population.

Keywords: Smoking status, UCP2, variant, PCR-RFLP

\section{ÖZ}

Amaç: Mitokondriler hücrelerde bulunan çok fonksiyonlu ve dinamik organellerdir. Nikotin tütün bitkisinde bulunan doğal bir alkaloiddir ve sigara içme durumunun iyi çalışılmış bir bileşenidir. Nikotinin in vitro ve in vivo olarak mitokondriyal fonksiyonu etkilediği rapor edilmiştir. Uncoupling protein 2 (UCP2) mitokondri ile ROS üretimini azaltır. Bu çalışmadaki amacımız UCP2-866G/A varyantının sigara içme durumu ile ilişkili olup olmadığını araştırmaktır.

Yöntemler: Yüz otuz sekiz sigara içen ve 100 sağlıklı kontrolden oluşan toplam 238 kişi değerlendirildi. UCP2-866G/A varyantı polimeraz zincir reaksiyonu-sınırlayıcı enzim parça uzunluk çeşitliliği metodu ile genotiplendi.

Bulgular: Üç olası genotipi taşıyan kişileri oranı sigara içenler ve sağlıklı kontrol grupları arasında belirgin şekilde farklıydı. UCP2866G/A varyantı AA genotipi belirgin şekilde azalmış sigara içme riski ile ilişkiyken ( $p=0,001)$, GG genotipi belirgin şekilde artmış sigara içme durumu ile ilişkiliydi ( $\mathrm{p}=0,001)$. UCP2-866G/A varyant $\mathrm{G}$ alelinin sigara içen grupta sağlıklı kontrollere göre artmış olduğu bulundu ( $\mathrm{p}=0,001)$.

Sonuç: Verilerimiz UCP2-866 G/A varyant GG genotip ve G alelin Türk popülasyonundaki sigara içme riskini yansıtabileceğini desteklemektedir.

Anahtar Sözcükler: Sigara içme durumu, UCP2, varyant, PCRRFLP
Address for Correspondence: Ayşe Feyda NURSAL, Hitit University Faculty of Medicine, Department of Medical Genetics, Çorum, Turkey

E-mail: feyda.nursal@gmail.com ORCID ID: orcid.org/0000-0001-7639-1122
Received: 07.02.2020

Accepted: 24.04 .2020

Cite this article as: Nursal AF, Uysal MA, Pehlivan M, Sever Ü, Pehlivan S. Impact of UCP2 -866G/A Variant on Smoking Risk. Bezmialem Science 2021;9(2):185-9. 


\section{Introduction}

Mitochondria, which are found nearly in all eukaryotic cells, play an important role in many cellular functions. These organelles are often referred to as the "powerhouse" of cells because they provide approximately $90 \%$ of the energy needed for survival (1). The mitochondria is essential for adenosine triphosphate (ATP) production through oxidative phosphorylation (OXPHOS). In addition, they are involved in several other cell processes such as cell differentiation, calcium signaling, and apoptosis, as well as cell cycle control and cellular growth (2). Mitochondrial function impairment is related to the pathogenesis of several serious diseases due to the complexity of mitochondrial physiology. Decrease in mitochondrial function manifested by the following: lower mitochondrial membrane potential, alterations in electron transport chain complex activities, reduced ATP synthesis, inefficient $\mathrm{Ca}^{2+}$ buffering, enhanced reactive oxygen species (ROS) synthesis, modified mitochondrial dynamics, or release of pro-apoptotic factors found during aging and in many chronic diseases such as cardiovascular diseases, diabetes, cancer, and numerous metabolic syndromes (3).

Nicotine is the main active component of cigarettes that is involved in physical dependence, affecting nicotine receptors in the central nervous system that leads to the release of neurotransmitters [including dopamine (DA)]. Nicotine activates dopaminergic neurons in the mesolimbic reward system and facilitates DA release (4). Some studies reported inhibitory effects of nicotine on the OXPHOS machinery. Cormier et al. (5) showed that nicotine inhibits oxygen consumption of isolated rat brain mitochondria depending on its concentration. Smoking lowers arterial oxygen carrying capacity via increased serum carboxyhemoglobin levels that leads to OXPHOS dysfunction in cardiac cells (6). Rats exposed to passive cigarette smoke from two cigarettes per day for two months manifest seriously impaired myocardial OXPHOS function during reperfusion injury (7). This impact of nicotine on mitochondrial oxygen consumption indicates its direct effect on respiratory chain complexes.

Mitochondrial uncoupling proteins (UCPs) constitute a group of mitochondrial anion carriers that seem to be involved in proton transmission across the inner membrane, which can be related to thermogenesis, and play a role in regulating mitochondrial membrane potential, hence, generating mitochondrial ROS (8). UCP2 gene belongs to this superfamily and covers a $6.3 \mathrm{~kb}$ region on chromosome 11 (region 11q13) and has eight exons and seven introns (9). UCP2 is universally expressed at different levels in various tissues such as the skeletal muscle, heart, lung, spleen, thymus, and brain (10). The -866G/A (rs659366) variant of UCP2 is found in the cis regulatory site of the promoter region. It has been found to be a functional variant on gene expression, and the variant could alter UCP2 function. Thus, this study aimed to investigate whether the $-866 \mathrm{G} / \mathrm{A}$ gene variant (rs659366) of the UCP2 gene is associated with smoking status in the Turkish population.

\section{Methods}

\section{Study Population}

This cross-sectional association study included 138 smokers and 100 healthy controls. Participants were selected among the individuals from Yedikule Chest Diseases and Thoracic Surgery Training and Research Hospital, İstanbul, Turkey. Data on the average amount of tobacco consumed per day was recorded from all participants. The degree of smoking status was evaluated by the scores on Heaviness of Smoking Index and the Fagerström Test for Nicotine Dependence (11). Healthy volunteers (control group) were selected from the voluntaries who were nonsmokers. All participants were of Turkish origin, and a written informed consent was obtained from each. The experimental study protocol and process was assessed and approved by the ethics committee (İstanbul Medical Faculty, 2015/17).

\section{Genotyping}

Blood samples were obtained from participants. Genomic deoxyribonucleic acid was isolated from whole blood by salting out method (12). Genotyping of the $-866 \mathrm{G} / \mathrm{A}$ variant in the promoter region of the UCP2 gene was performed by polymerase chain reaction (PCR)-restriction fragment length polymorphism method as previously described (13). Primer sequence 5'CAC GCT GCT TCT GCC AGG AC-3' and 5'-AGG CGT CAG GAG ATG GAC CG-3' were used to amplify -866G/A variant of $U C P 2$ gene. After amplification, PCR products were subjected to restrict digestion using Mlu 1 (Invitrogen) for all night at $37 \mathrm{C}$. Fragment amplification and digestion results were revealed by $2 \%$ agarose gel electrophoresis and visualized on a ultraviolet transilluminator after ethidium bromide staining.

\section{Statistical Analysis}

All data were analyzed by using the Statistical Package for the Social Sciences (SPSS) for Windows (version 16.0; SPSS Inc, Chicago, IL, USA). The $\chi 2$-test was used for statistical analysis of genotype and allele frequencies in case and control groups (GraphpadInstat version 3, Graphpad Software, San Diego, CA, USA). Results are given as mean \pm standard deviation, whereas allele frequencies and distribution of genotypes are given as percentages (\%). The Hardy-Weinberg equilibrium (HWE) was calculated using the De-finetti program (Online HWE and Association Testing- InstitutfürHumangenetik, Munich, Germany). Statistical significance was considered at $\mathrm{p}<0.05$.

\section{Results}

Our study includes 238 individuals, 138 smokers and 100 ethnicity-matched healthy controls. The allele and genotype frequencies of UCP2 -866G/A variant for smoking participants versus controls are shown in Table 1 . The proportion of individuals carrying three possible genotypes (-866G/G, -866G/ $\mathrm{A}$, and $-866 \mathrm{~A} / \mathrm{A}$ ) was significantly different between controls and smoker groups. The UCP2 -866G/A variant $\mathrm{G} / \mathrm{G}$ genotype was more common in smoker groups compared to the control group $[\mathrm{p}=0.001$, odds ratio $(\mathrm{OR}): 0.213,95 \%$ confidence interval $(\mathrm{Cl})$ : 0.116-0.392], whereas the A/A genotype was lower in smoker 
group compared to the control ( $\mathrm{p}=0.001$, OR: $3.664,95 \% \mathrm{Cl}$ : 2.000-6.713). The UCP2 -866G/A variant $\mathrm{G}$ allele was increased in smoker group than the control group ( $\mathrm{p}=0.001$, OR: 3.301 , 95\% Cl: 2.257-4.828). The observed genotype counts deviated significantly from those expected in smoker group according to the HWE for UCP2 -866G /A variant.

\section{Discussion}

Mitochondria are indispensable organelles in all eukaryotic cells, modulating many crucial vital processes for cell viability and function, such as energy generation, redox control, calcium homeostasis, and several metabolic and biosynthetic pathways. The mitochondrial respiratory chain is the main source of intracellular ROS production, as well as a significant target for the harmful effects of ROS (14). Causing various physiologic and biochemical consequences generated by cigarette smoke components, tobacco use is a serious health issue. Cigarette smoking initiates oxidative stress in several organs such as the brain and plays a role in numerous diseases, such as cognitive or neurodegenerative pathological changes (15). Nicotine can pass through the blood-brain barrier and end up in high levels in the brain tissue within 10-20 s following inhalation (16). Nicotine in similar amounts to those in cigarette smoke can lead to oxidative stress, as shown in vitro and in vivo (17). Changes in brain energy metabolism indicated the role of mitochondria, the key players in cellular energy production. Cigarette smoking can result in mitochondrial dysfunction (18), as shown by elevated cholesterol, lipid peroxides, and increased cholesterol/ phospholipid ratio, along with reduced mitochondrial enzymes in those exposed to cigarette smoke (19).

UCPs can dissociate mitochondrial oxidation from phosphorylation, decreasing mitochondrial energy generation and augment cell thermogenesis. So, far, UCPs has been given attention for their role in peripheral energy metabolism, where their energy-dissipating function has been uncovered primarily with regard to metabolic disorders. In the central nervous system, mammalian UCP2 messenger ribonucleic acid and protein expression is most prominent in regions that could be depicted as high risk for stress (20). High risk areas have direct access to the blood stream, axons, and axon terminals abundant in the hypothalamus, neural circuits crucial for the endocrine and homeostatic regulation, and those related to neurodegenerative disease like the substantia nigra and locus coeruleus (20). The hippocampus is a significant brain structure in both cognitive and emotional functions (21). UCP2-knockout mice were significantly more anxious in the elevated plus-maze than wildtype mice in a behavioral study with an anxiety setting (22). In addition, UCP2 seems to be involved in neuronal plasticity and regeneration (23). Most of these studies suggest an important role of UCP2 in the maintenance of cognitive functions and anxiety resistance. Thus, lack of UCP2 may impair the endocrine, mitochondrial bioenergetics, and thermoregulation of the neurons, which are related to cognition, mood, and behavior. In the brain, the DA turnover is modified in UCP2-deficient (UCP2-/-) mice, and the number of mitochondria in neurons of the substantia nigra and the ventral tegmental area is decreased in UCP2-/- mice, whereas ROS generation is increased (24). Brain DA is known to play a central role in addictive disorders including nicotine addiction. Besides, Li et al. (25) demonstrated that chronic nicotine use significantly lowered UCP2 in the cerebral cortex and cerebral arteries in rats.

Polymorphisms within the UCP2 gene have been reported to be related with several metabolic traits including obesity and type 2 diabetes. A functional -866G/A variant has been identified in the UCP2 promoter and is found in a multifunctional cis regulatory site with functional consequences. The $-866 \mathrm{~A}$ allele has been found to elevate UCP 2 transcriptional activity in transfected cultured cells (26); however, data in human tissues have been conflicting (27). In this study, we hypothesized that the $-866 \mathrm{G} / \mathrm{A}$ variant of the UCP2 gene is associated with risk of smoking status in the Turkish population. To our knowledge, for the first time in the literature, we have demonstrated a significant association of the UCP2 functional variant with smoking status in the Turkish cohort. We found that participants carrying UCP2 -866G/A variant GG genotype showed a higher risk for smoking (Table 1). The participants carrying UCP2 -866G/A variant AA genotype and A allele may have protective effects in smoking for the Turkish population $(\mathrm{p}<0.05)$ (Table 1$)$. The observed overall genotype distribution in smoker group was not consistent with HWE.

\section{Study Limitations}

Several limitations were encountered in this analysis. Firstly, only one variant of UCP2 gene was evaluated. Other variants of this

Table 1. Genotype and allele distribution of UCP2 -866G/A variant in case and control groups

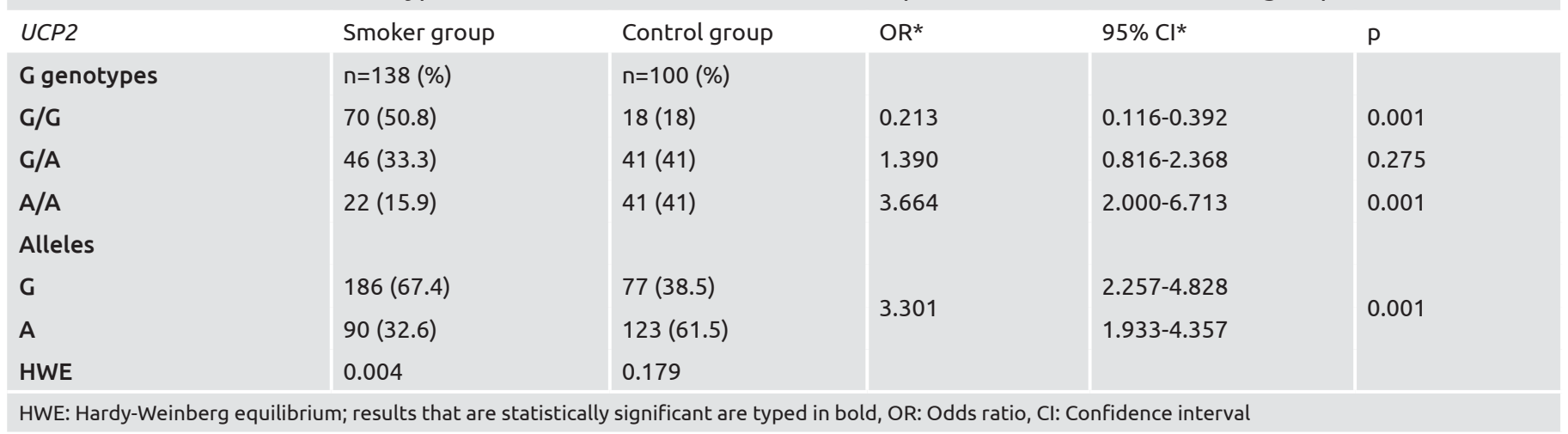


gene may also susceptibly play a role. Additionally, the gene-gene and gene-environment interactions were not discussed for the $U C P 2$ variant due to lack of original information.

\section{Conclusion}

In conclusion, our observation suggests that the UCP2 -866G/A variant GG genotype and $G$ allele may create a predisposition to smoking. Therefore, UCP2 gene should be considered as candidate gene for both smoking status in the Turkish population. However, further long-term and large-scale studies are required to confirm issues regarding the mechanisms underlying the observed association.

\section{Ethics}

Ethics Committee Approval: The experimental study protocol and process was assessed and approved by the ethics committee (İstanbul Medical Faculty, 2015/17).

Informed Consent: All participants were of Turkish origin, and a written informed consent was obtained from each.

Peer-review: Externally peer reviewed.

\section{Authorship Contributions}

Data Collection or Processing: M.A.U., Ü.S., S.P., Analysis or Interpretation: A.F.N., M.A.U., Ü.S., S.P., Literature Search: A.F.N., M.P., Writing: A.F.N., M.P.

Conflict of Interest: No conflict of interest was declared by the authors.

Financial Disclosure: This study was supported by the İstanbul University BAP (BEK: 2017-25175 and TYL: 2414-50695) program.

\section{References}

1. Dimijian GG. Evolving together: the biology of symbiosis, part 2 . Proc (Bayl Univ Med Cent) 2000;13:381-90.

2. Sadakierska-Chudy A, Frankowska M, Filip M. Mitoepigenetics and drug addiction. Pharmacol Ther 2014;144:226-33.

3. Malińska D, Więckowski MR, Michalska B, Drabik K, Prill M, Patalas-Krawczyk P, et al. Mitochondria as a possible target for nicotine action. J Bioenerg Biomembr 2019;51:259-76.

4. Jin Y, Chen D, Hu Y, Guo S, Sun H, Lu A, et al. Association between monoamine oxidase gene polymorphisms and smoking behaviour in Chinese males. Int J Neuropsychopharmacol 2006;9:557-64.

5. Cormier A, Morin C, Zini R, Tillement JP, Lagrue G. Nicotine protects rat brain mitochondria against experimental injuries. Neuropharmacology 2003;44:642-52.

6. Van Jaarsveld H, Kuyl JM, Alberts DW. Antioxidant vitamin supplementation of smoke-exposed rats partially protects against myocardial ischaemic/reperfusion injury. Free Radic Res Commun 1992;17:263-9.

7. van Jaarsveld H, Kuyl JM, Alberts DW. Exposure of rats to low concentration of cigarette smoke increases myocardial sensitivity to ischaemia/reperfusion. Basic Res Cardiol 1992;87:393-9.
8. Garlid KD, Jaburek M, Jezek P. Mechanism of uncoupling protein action. Biochem Soc Trans 2001;29:803-6.

9. Souza BM, Assmann TS, Kliemann LM, Gross JL, Canani LH, Crispim D. The role of uncoupling protein 2 (UCP2) on the development of type 2 diabetes mellitus and its chronic complications. Arq Bras Endocrinol Metabol 2011;55:239-48.

10. Richard D, Clavel S, Huang Q, Sanchis D, Ricquier D. Uncoupling protein 2 in the brain: distribution and function. Biochem Soc Trans 2001;29:812-7.

11. Heatherton TF, Kozlowski LT, Frecker RC, Fagerström KO. The Fagerström Test for Nicotine Dependence: a revision of the Fagerström Tolerance Questionnaire. Br J Addict 1991;86:1119-27.

12. Miller SA, Dykes DD, Polesky HF. A simple salting out procedure for extracting DNA from human nucleated cells. Nucleic Acids Res 1988; $16: 1215$.

13. Srivastava N, Prakash J, Lakhan R, Agarwal CG, Pant DC, Mittal B. A common polymorphism in the promoter of UCP2 is associated with obesity and hyperinsulenemia in northern Indians. Mol Cell Biochem 2010;337:293-8.

14. Echtay KS. Mitochondrial uncoupling proteins--what is their physiological role? Free Radic Biol Med 2007;43:1351-71.

15. Le Houezec J. Role of nicotine pharmacokinetics in nicotine addiction and nicotine replacement therapy: a review. Int J Tuberc Lung Dis 2003;7:811-9.

16. Vani G, Anbarasi K, Shyamaladevi CS. Bacoside A: Role in Cigarette Smoking Induced Changes in Brain. Evid Based Complement Alternat Med 2015;2015:286137.

17. Zhang XY, Tan YL, Zhou DF, Haile CN, Wu GY, Cao LY, et al. Nicotine dependence, symptoms and oxidative stress in male patients with schizophrenia. Neuropsychopharmacology 2007;32:2020-4.

18. Anbarasi K, Vani G, Devi CS. Protective effect of bacoside A on cigarette smoking-induced brain mitochondrial dysfunction in rats. J Environ Pathol Toxicol Oncol 2005;24:225-34.

19. Moylan S, Jacka FN, Pasco JA, Berk M. How cigarette smoking may increase the risk of anxiety symptoms and anxiety disorders: a critical review of biological pathways. Brain Behav 2013;3:302-26.

20. Normoyle KP, Kim M, Farahvar A, Llano D, Jackson K, Wang H. The emerging neuroprotective role of mitochondrial uncoupling protein-2 in traumatic brain injury. Transl Neurosci 2015;6:179-86.

21. Cornwell BR, Arkin N, Overstreet C, Carver FW, Grillon C. Distinct contributions of human hippocampal theta to spatial cognition and anxiety. Hippocampus 2012;22:1848-59.

22. Gimsa U, Kanitz E, Otten W, Aheng C, Tuchscherer M, Ricquier D, et al. Alterations in anxiety-like behavior following knockout of the uncoupling protein 2 (ucp2) gene in mice. Life Sci 2011;89:677-84.

23. Dietrich MO, Andrews ZB, Horvath TL. Exercise-induced synaptogenesis in the hippocampus is dependent on UCP2-regulated mitochondrial adaptation. J Neurosci 2008;28:10766-71.

24. Andrews ZB, Rivera A, Elsworth JD, Roth RH, Agnati L, Gago B, et al. Uncoupling protein-2 promotes nigrostriatal dopamine neuronal function. Eur J Neurosci 2006;24:32-6. 
25. Li C, Sun H, Arrick DM, Mayhan WG. Chronic nicotine exposure exacerbates transient focal cerebral ischemia-induced brain injury. J Appl Physiol (1985) 2016;120:328-33.

26. Krempler F, Esterbauer H, Weitgasser R, Ebenbichler C, Patsch $\mathrm{JR}$, Miller K, et al. A functional polymorphism in the promoter of
UCP2 enhances obesity risk but reduces type 2 diabetes risk in obese middle-aged humans. Diabetes 2002;51:3331-5.

27. Wang H, Chu WS, Lu T, Hasstedt SJ, Kern PA, Elbein SC. Uncoupling protein-2 polymorphisms in type 2 diabetes, obesity, and insulin secretion. Am J Physiol Endocrinol Metab 2004;286:1-7. 